\title{
THE ODONATA COMMUNITY OF A BRAZILIAN VEREDA: SEASONAL PATTERNS, SPECIES DIVERSITY AND RARITY IN A PALM SWAMP ENVIRONMENT
}

\author{
A COMUNIDADE DE ODONATOS DE UMA VEREDA BRASILEIRA: PADRÕES \\ SAZONAIS, DIVERSIDADE DE ESPÉCIES E RARIDADE EM UM AMBIENTE DE \\ BURITIZAL
}

\author{
Diogo Silva VILELA ${ }^{\mathbf{1}}$; Rhainer Guillermo FERREIRA ${ }^{\mathbf{2}}$; Kleber DEL-CLARO ${ }^{3}$ \\ 1. Graduate Program in Entomology, University of São Paulo, FFCLRP, Ribeirão Preto, SP, Brazil. deeogoo@ gmail.com; 2. Federal \\ University of São Carlos UFSCar, São Carlos, SP Brazil; 3. Federal University of Uberlândia UFU, Uberlândia, MG Brazil.
}

\begin{abstract}
Studies concerning the occurrence of species and seasonality are of great importance for both the elucidation of species distribution and conservation of natural habitats. We performed a survey of Odonata species and studied their seasonality in an endemic endangered palm swamp (i.e. Veredas) environment of the Ecological Reserve of Clube de Caça e Pesca Itororó de Uberlândia, Southestern Brazil. Between July 2010 and June 2011, we recorded 31 species of five different families and 21 genera. The community was strongly seasonal, since 24 species occurred in the wet season, while ten occurred in both dry and wet season, and only two species occured only in the dry season. All Anisoptera species preferred lentic habitats, whereas seven of the 18 Zygopera species preferred lentic habitats and 11 species preferred lotic sites. The five Calopterygidae and Protoneuridae species preferred lotic habitats. The study site exhibits a great diversity of dragonflies and damselflies, which are important elements of the trophic chain in the Cerrado aquatic and neighboring land environments. This justifies the development of conservation actions in palm swamp areas, which are poorly known and threatened by the constant advance of urban, monoculture and pasture areas in Cerrado.
\end{abstract}

KEYWORDS: Wetland. Conservation. Checklist. Dragonflies.

\section{INTRODUCTION}

Basic studies of local species assemblages and seasonality are of great importance for both the elucidation of species distribution and conservation of natural habitats (OPLER, 1991; KIM, 1993; DE ANDRADE et al., 2011; DEL-CLARO et al., 2013a). In Brazil, the Cerrado (i.e. the Neotropical Savanna) exhibits a well defined seasonality: a dry period from April to September, and a rainy period between October and March (ARAÚJO et al. 2013; VILELA et al., 2014).

The Cerrado is the second largest biome in Brazil, comprising over two million square kilometres. This biome is composed by plateaus with an endless lotic ecosystem network of rivers and streams, and they are home to one third of all countrywide biodiversity (FONSECA, 2005; GOTTSBERGER; SILBEBAUERGOTTSBERGER, 2006). Despite being one of the most important ecosystems, the Cerrado has been the most degraded biome in the past decades, with over $40 \%$ of its area lost to large pastures and monoculture (FONSECA, 2005). Inside this biome, there are many phytophysiognomic types, which occur according to the soil characteristics and water availability (OLIVEIRA; MARQUIS, 2002 Chapter $1)$.
Among the Cerrado physiognomies, the Veredas (i.e. palm swamps) are highly conspicuous environments associated with freshwater bodies that naturally occur throughout most of the South American Cerrado (FONSECA, 2005; ARAÚJO et al. 2013). Palm swamps are characterized by its permanently water saturated soils (FONSECA, 2005), and hold a great biodiversity, always associated to the palm tree Mauritia flexuosa $\mathrm{L}$. f. (Arecales: Arecaceae) (ARAÚJO et al. 2002, 2013; OLIVEIRA; MARQUIS, 2002).

In these freshwater environments, the invertebrates, mainly the aquatic insects, are excellent research models because of their diversity, their gradients of preference in space and time (e.g. seasonal patterns), and their life cycle that comprises both aquatic and terrestrial environments (DJIKSTRA, 2014). The insects are one of the most diverse and well-studied organisms, and its importance to the environment has been tested and confirmed by several studies worldwide (BORROR et al., 1989; NAKAMURA, 2011; SAMWAYS et al., 2012; BISCHOF et al., 2012; DEL-CLARO et al., 2013b).

Insects of the order Odonata (e.g. dragonflies and damselflies), the second largest purely aquatic order (DJIKSTRA, 2014), are known as important components of the trophic web in their 
associated environments, and their larvae are seen as natural bioindicators of environmental conservation (CORBET, 1999; JUEN et al., 2014). Although large among the aquatic insects, with almost 6.000 described species, the order is relative small if compared to other insect groups (CORBET, 1999). On the other hand, it is the aquatic insect group with the largest number of studied species (DJIKSTRA, 2014). Furthermore, dragonflies are cosmopolitan, inhabiting almost all freshwater environments (CORBET, 1999; KALKMAN, 2008).

The fact that odonates need freshwater bodies for oviposition and larvae development makes them strongly dependent on these environments, in which seasonality is an important factor influencing the occurrence and distribution of populations along the year (CORBET, 1999; DJIKSTRA, 2014). Climate changes and human impacts are altering the hydrology of Cerrado, and consequently freshwater organisms (KLINK; MACHADO, 2005). Despite its importance, little attention has been directed to the conservation of freshwater systems and the aquatic biota in Veredas, highlighting the importance of studies related to the conservation of these areas where river sources are abundant (FONSECA, 2005).

We performed a survey of the Odonata community in a palm swamp environment in the Brazilian Cerrado, in order to identify species richness, behavioral and seasonality patterns.
Several studies were conducted in the same area before, revealing that there is a great variety of habitats and territorial preferences, associated with plants for oviposition, and parasitism (ALVESMARTINS et al., 2012; GUILLERMO-FERREIRA; DEL-CLARO, 2011，2012，2013; GUILLERMOFERREIRA; VILELA, 2012, 2013; GUILLERMOFERREIRA; BISPO, 2012). Our main goal was to evidence that Veredas support a highly diverse and seasonal Odonata community, which justify conservation policies for Brazilian palm swamp areas.

\section{MATERIAL AND METHODS}

\begin{abstract}
Study area
The study was conducted in palm swamp habitats within the Ecological Reserve of the Clube de Caça e Pesca Itororó de Uberlândia (CCPIU), in the state of Minas Gerais, southeastern Brazil $\left(18^{\circ} 59^{\prime} 00^{\prime \prime} \mathrm{S}, 48^{\circ} 18^{\prime} 00^{\prime \prime} \mathrm{W}\right)$. The climate is Tropical wet and dry (AW) according to the Köppen climate classification and its elevation is $880 \mathrm{~m}$ above the sea level. There is a large wetland area with an associated pond (Figure 1 a), one stream (Figure $1 \mathrm{~b}$ ) and temporary pools. Although the Ecological Reserve limits comprise 640 ha, the pond (lentic) area is about 60 square meters and the stream (lotic) length is about 500 meters (Figure 1).
\end{abstract}

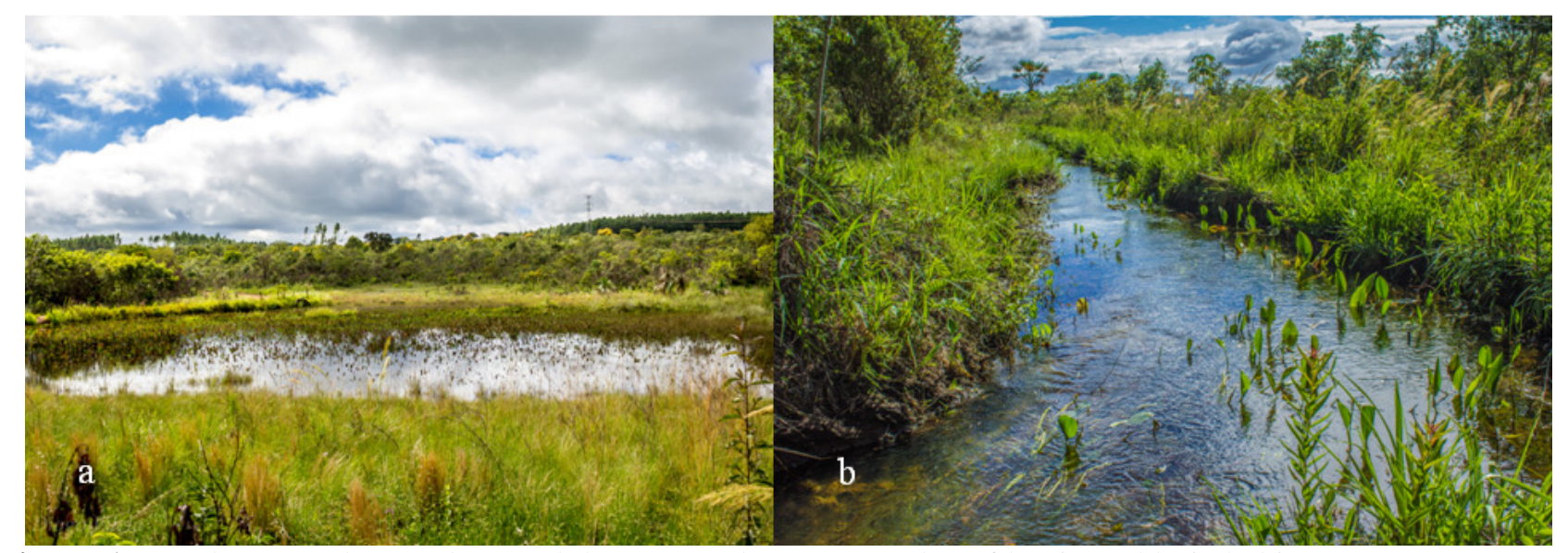

Figure 1 - Study area. The pond (a) and the stream (b), as examples of lentic and lotic habitats.

\section{Sampling procedures}

The study was carried out between July 2010 and June 2011, when surveys were conducted to determine the number of Odonata species and whether species occurrence is determined by seasonality. Sampling sessions were carried out between 10:00 and 15:00, when activity is higher (CORBET, 1999). In order to observe particular habitat preferences according to sunlight incidence, water flow and oviposition sites, we divided the study area in five transects. Four of these transects were set along the pond margins and one transect was set on the first 25 meters of the stream. Three transects had total solar incidence (i.e. pond), while one transect was partially shaded (i.e. stream). 
We sampled adult odonates every two weeks in each transect for 30 minutes with an entomological net. Each transect was sampled twice, 15 minutes per session. Collected individuals were taken to the laboratory for posterior identification and deposition in the collection of the Aquatic Insects Lab of the Federal University of São Carlos. The identifications were made by a specialist (RGF) with the aid of identification keys (LENCIONI, 2005, 2006; GARRISON, 2006).

\section{Behavioral observations}

At the end of specimen collections, we conducted behavioral observations on the preferred perch habitat of each species (lentic or lotic), mateguarding type, male territoriality and oviposition substrates used by females. For these observations, we followed the focal animal method described by Altmann (1974), when a single individual was observed for 10 minutes and we took notes on the exhibited behaviors. Territoriality was defined for some species where males defend a patch of the pond or stream margins, frequently fighting with other males and defending the territory (CORBET, 1999). Mate-guarding and oviposition behaviors were recorded wherever possible. We followed mating couples until the female started oviposition, noting the oviposition substrate and mate-guarding tactic adopted by males. Oviposition events were categorized as exophytic, when the females lay the eggs on roots and debris and on the surface of aquatic plants and endophytic, when the females place its eggs inside plants stalks. The mateguarding tactic events were categorized in three forms: female alone (FA), when a female lay its eggs with no male guarding; in tandem (IT), the male grabs the female with his appendages while the oviposition and no contact (NC), when the male follows the females as she oviposits. During behavioral observation sessions, we dedicated at least 30 minutes of observation for each species when possible.

\section{Seasonal patterns}

Seasonality was determined according to the two well defined seasons of Cerrado, which are: the dry season, comprising the months from April to September, and the wet season, comprising the months from October to March (MARQUES ; DELCLARO, 2006; VILELA et al., 2014; FERREIRA; TOREZAN-S ILINGARDI, 2013). Therefore, the seasonal occurrence of the species was based on the month of capture and observation of adults.

\section{Species richness}

To evaluate our sampling method we made a collector curve on the program EstimateS $® 9.1$ (COLWELL, 2005). This collector curve allows us to verify if we had enough samples based on the stabilization of the curve along the $\mathrm{x}$ axis. The number of sampled species increases as the samples are performed and the stabilization of the collector curve indicates if we have enough samples (COLWELL, 2005). Furthermore, the collector curve allows us to compare our data on observed species richness with a richness estimator (Jack 2).

\section{RESULTS}

Altogether, 31 species (18 Zygoptera and 13 Anisoptera) of five families and 21 different genera were recorded. With 12 species, Coenagrionidae was the dominant family within the Zygoptera. The Anisoptera were almost exclusively represented by libellulids, with the exception of some Aeshnidae species (Table 1).

Some behavioral observations could be performed for the most common species in the study area (see Table 1). The preferential habitat was observed for all species. All Anisoptera species had preference for lentic habitats, whereas seven of the 13 Zygoptera species preferred lentic habitats and ten species preferred lotic sites. The five Calopterygidae and Protoneuridae species preferred lotic habitats.

The oviposition events were recorded for 16 species and male territorial behavior was inferred for some species, although previous research in the same area have detailed the behavior of some species such as Argia reclusa, Acanthagrion truncatum and Oxyagrion microstigma (see, GUILLERMO-FERREIRA; Del-Claro, 2011, 2012a, 2012b). The observed oviposition patterns showed that, with the exception of Erythemis vesiculosa (Fabricius, 1775), all Anisoptera species seem not to have a particular oviposition site. Anisoptera females oviposit, in its majority, guarded by a male. In contrast, zygopterans adopt a more diverse range of strategies during oviposition. Coenagrionidae species can oviposit endophytically in branches of Eleocharis or within roots and debris. Calopterygidae females can also submerge when laying eggs, likewise Neoneura sylvatica (Hagen in Selys, 1886). 
Table 1. Odonata species found in a Brazilian palm swamp area (Vereda), occurrence between the dry and wet season, freshwater habitat selection, oviposition behavior, mate-guarding behavior (MGB) and territoriality. FA: female alone; IT: in tandem; NC: no contact; T: territorial; NT: non-territorial; ND: no data recorded in the study area. * First record to Minas Gerais state.

\section{CALOPTERYGIDAE}

Hetaerina rosea Selys, 1853

Mnesarete lencionii Garrison, 2006

Mnesarete pudica Hagen in Selys, 1853

\section{COENAGRIONIDAE}

Acanthagrion lancea Selys, 1876

Acanthagrion truncatum Selys, 1876

Argia hasemani Calvert, 1909

Argia reclusa Selys, 1865

Argia smithiana Calvert, 1909

Cyanallagma ferenigrum De Marmels, 2003*

Cyanallagma nigrinuchale Selys, 1876

Homeoura chelifera Selys, 1876*

Ischnura capreolus Hagen, 1861

Minagrion waltheri Selys, 1876*

Oxyagrion microstigma Selys, 1876

Telebasis carmesina Calvert, 1909

Tigriagrion aurantinigrum Calvert, 1909

\section{PROTONEURIDAE}

Neoneura sylvatica Hagen in Selys, 1886

Epipleoneura williamsoni Santos, 1957

\section{ANISOPTERA}

AESHNIDAE

Coryphaeshna adnexa Hagen, 1861 LIBELLULIDAE

Diastatops obscura Fabricius, 1775 Erythemis credula Hagen, 1861

Erythemis vesiculosa Fabricius, 1775

Erythrodiplax fusca Rambur, 1842

Erythrodiplax juliana Ris, 1911

Erythrodiplax latimaculata Ris, 1911

Erythrodiplax umbrata Linnaeus, 1758

Erythrodiplax sp. nov.

Micrathyria hesperis Ris, 1911

Orthemis aequilibris Calvert, 1909

Orthemis discolor Burmeister, 1839

Zenithoptera lanei Santos, 1941

$\begin{array}{cc}\begin{array}{c}\text { Dry } \\ \text { season }\end{array} & \begin{array}{c}\text { Wet } \\ \text { season }\end{array} \\ X & X \\ & X \\ X & X\end{array}$

Habitat
lotic
lotic
lotic

MGB

IT-NC
ND

\begin{tabular}{|c|c|c|c|}
\hline$X$ & $X$ & lentic & FA \\
\hline$X$ & $X$ & lentic & IT \\
\hline \multirow{4}{*}{ X } & $X$ & lotic & ND \\
\hline & $\mathrm{X}$ & lotic & FA-IT \\
\hline & $X$ & lotic & ND \\
\hline & $X$ & lentic & ND \\
\hline$X$ & & lotic & FA \\
\hline X & & lotic & IT \\
\hline \multirow[t]{2}{*}{ X } & X & lentic & FA \\
\hline & $X$ & lentic & ND \\
\hline \multirow{3}{*}{$X$} & $X$ & lentic & IT \\
\hline & $X$ & lentic & IT \\
\hline & $X$ & lotic & ND \\
\hline
\end{tabular}

$\mathrm{X}$

lotic

$\mathrm{X}$

lotic
FA

\section{Oviposition in}

Roots and debris ND

Roots, debris and submerged vegetation

Eleocharis sp.

(Endophytic)

Eleocharis sp.

(Endophytic) ND

Roots and debris ND

Roots and debris

$$
\begin{aligned}
& \text { Pontederia } \\
& \text { parviflora }
\end{aligned}
$$

ND

ND

ND

Eleocharis sp.

Eleocharis sp.

(Endophytic)

ND

IT

Submerged

vegetation and aquatic plants

Aquatic plants and debris

\section{Territoriality}

$\mathrm{T}$

$\mathrm{T}$

$\mathrm{T}$

NT

NT

ND

$\mathrm{T}$

ND

$\mathrm{T}$

NT

NT

NT

NT

T-NT

NT

$\mathrm{T}$

ND

\begin{tabular}{|c|c|c|c|c|c|}
\hline & $\mathrm{X}$ & lentic & ND & ND & ND \\
\hline & $X$ & lentic & $\mathrm{NC}$ & Exophytic & $\mathrm{T}$ \\
\hline & $X$ & lentic & ND & ND & ND \\
\hline & $\mathrm{X}$ & lentic & FA & $\begin{array}{c}\text { Pontederia } \\
\text { parviflora }\end{array}$ & ND \\
\hline \multirow[t]{2}{*}{$\mathrm{X}$} & $X$ & lentic & $\mathrm{NC}$ & ND & $\mathrm{T}$ \\
\hline & $X$ & lentic & $\mathrm{NC}$ & Exophytic & $\mathrm{T}$ \\
\hline \multirow[t]{2}{*}{$\mathrm{X}$} & $X$ & lentic & $\mathrm{NC}$ & ND & $\mathrm{T}$ \\
\hline & $X$ & lentic & FA & ND & $\mathrm{T}$ \\
\hline \multirow[t]{5}{*}{$\mathrm{X}$} & $X$ & lentic & $\mathrm{NC}$ & ND & $\mathrm{T}$ \\
\hline & $X$ & lentic & $\mathrm{NC}$ & ND & ND \\
\hline & $X$ & lentic & $\mathrm{NC}$ & Exophytic & ND \\
\hline & $\mathrm{X}$ & lentic & $\mathrm{NC}$ & Exophytic & $\mathrm{T}$ \\
\hline & $X$ & lentic & $\begin{array}{c}\text { IT-FA- } \\
\text { NC }\end{array}$ & Exophytic & NT \\
\hline
\end{tabular}

ND 
Twenty-one of the 31 species recorded in the study area occurred only in the dry or the wet season. Another ten species were found in both seasons, of which seven were Zygoptera and three Anisoptera. Ten out of 13 Anisoptera and nine out of 18 Zygoptera species occurred just in the rainy season. Only two species occurred solely in the dry season, which were Cyanallagma nigrinuchale (Selys, 1876) and Homeoura chelifera (Selys, 1876).

\section{Habitat preferences}

Our results show that some families preferred specific habitats. For instance, Calopterygidae and Protoneuridae individuals were only represented in the lotic transect (Transect 1) and the Stream Transect. Libellulidae and Coenagrionidae were more common at the lentic and sunny transects (Transects 2, 3 and 4; Figure 3).

\section{Species richness}

Our species sampling effort was efficient according to the richness estimator Jack1 (Figure 4). The observed richness curve shows that from the sample 79 we no longer captured new species, stabilizing the curve along the subsequent samples. On the other hand, the Jack 3 estimator curve stabilized on the sample 96.

Observed richness $\quad$ Jack 2

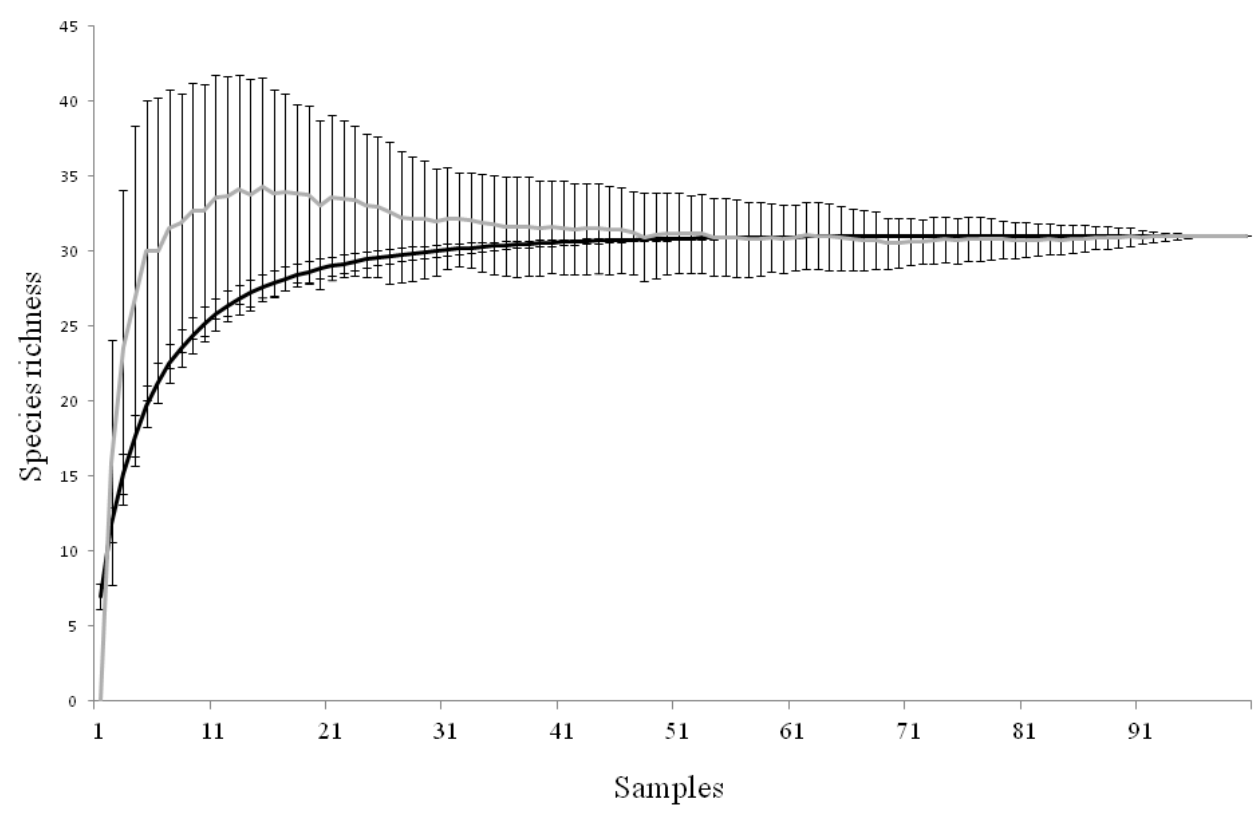

Figure 2. Collector curve showing the observed richness and the predicted richness by the estimator Jack2.

\section{DISCUSSION}

One of the hotspots for Odonata diversity worldwide is found in the Neotropical region, mainly Brazil (KALKMAN et al., 2008). Our results show that Veredas, an endemic Neotropical environment, can hold a diverse and seasonal Odonate community. In a relatively small pond and one stream, we found 31 Odonata species. Furthermore, our collector curve indicates that our sampling was enough to capture all the Odonata species present in our study area, as indicated by the stabilization of the species richness curve (SANTOS, 2003). Previous studies performed in larger Cerrado areas also showed important diversity of dragonfly and damselfly species (FERREIRA-PERUQUETTI;
GESSNER, 2003; CÔRTES et al. 2011; OLIVEIRA-JÚNIOR et al., 2013).

In these studies, it is discussed that microhabitat and habitat heterogeneity, such as lentic/lotic areas and sunlight exposure, are ecological traits that influence the composition of Odonata communities (FERREIRA-PERUQUETTI; FONSECA-GESSNER, 2003; OLIVEIRA-JÚNIOR et al., 2013). In other words, less species are expected to occur in more homogeneous areas. In our study area, the lentic habitats of the pond (Transects 2, 3 and 4) were preferred mainly by Libellulid and Coenagrionid species. The first transect delimited on the pond has a channel linked to the stream, conferring a lotic characteristic to this portion of the pond, in which Calopterygids and Protoneurids were found more often. It is known in 
literature that Calopterygids prefer lotic areas with a fast water flow (WARD; MILL, 2005), and at our study site they also seem to prefer such particular sites.

Considering that the occurrence of Odonata species is constrained by the limited availability of both lentic and lotic freshwater habitats (CORBET, 1999), our results suggests that Palm Swamp wetland environment holds a relevant Odonata diversity and justifies studies that have the conservation of these endangered areas as a particular goal. Further studies on other palms swamps are needed to test whether our site is exceptional, or, on the contrary a typical example. The Brazilian Cerrado holds a great variety of natural ponds, many of them from subterranean water outcrops (FONSECA, 2005). Palm Swamps are one example of these soaked environments on which several endemic vegetal and animal species rely to thrive (ARAÚJO et al. 2002; OLIVEIRA; MARQUIS, 2002). Despite of all these quality factors, these areas are constantly degraded by extraction of clay and peat, agriculture and illegal deforestation (OLIVEIRA; MARQUIS, 2002; FONSECA, 2005; $\quad$ GOTTSBERGER; SILBERBAUER-GOTTSBERGER, 2006; ARAÚJO et al. 2013).

In this context, the study area seems to be a hotspot of rare and threatened species, such as Cyanallagma ferenigrum, Homeoura chelifera, Minagrion waltheri, Mnesarete lencionii and Orthemis aequilibris (Figure 5) all of them recorded for the first time in Minas Gerais state in this study, with the exception of the latter (Heckman, 2008). Moreover, a new species of the genus Erythrodiplax (Libellulidae) inhabits this area and is being described.

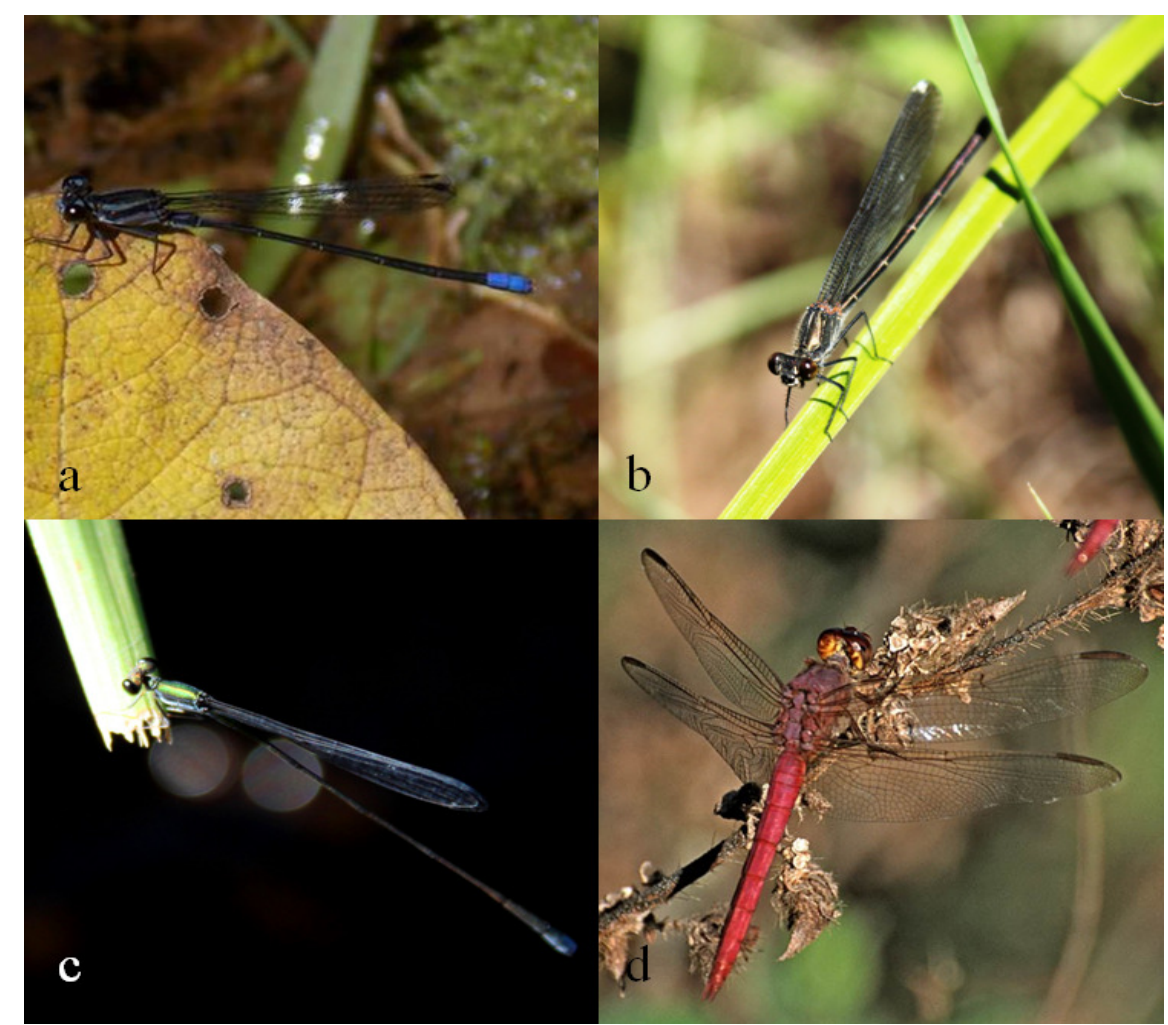

Figure 3. Rare species that occur in the studied Brazilian palm swamp. A - Argia smithiana; B - Mnesarete lencionii (female); C - Epipleoneura williamsoni; D - Orthemis aequilibris (Photo by Dennis Paulson)

It is known that freshwater environments are susceptible to seasonal changes, including physical and chemical characteristics that may influence the composition of invertebrate communities during different seasonal periods (BISCHOF et al. 2013; DJIKSTRA, 2014).. In Veredas palm swamps, a dry period of three to six months occurs regularly, leading to a significantly decrease in water depth.
The first rains are then incorporated by the hydromorphic soil, which is associated to the groundwater and associated water bodies (FONSECA, 2005).

Seasonality plays an important role in odonate development, mainly because there are changes in habitat and food availability (CORBET, 1999). Studies on Odonata larvae have shown that 
changes in environmental characteristics influence the community structure of this order (NOVELOGUTIERREZ, 2001; GÓMEZ-ANAYA, 2010). Thus, changes in the palm swamp hydrology can influence the seasonal composition of the odonate community. Our results showed that $68 \%$ of the species in the study area had their annual distribution restricted to the rainy season. Furthermore, two $(6,4 \%)$ species occurred solely in the dry season. Therefore, our results suggest that almost all the odonate species of the study area require the rainy period to complete their development.

The study of the aquatic biota of palm swamps is very important, especially odonates, since these organisms are essential components of the freshwater ecosystems trophic webs, regulators of the population of other insects, and great natural bioindicators (CORBET, 1999; JUEN et al., 2014).
Even though it is a relatively small insect order, Odonata plays an unquestionable role in the habitats they are associated with, and the present study aimed to contribute with information for future research on Odonata behavior, seasonality, occurrence and distribution in Brazilian palm swamps, in order to highlight the importance of this endemic wetland environment for the conservation of Neotropical odonates.

\section{ACKNOWLEDGEMENTS}

DSV thanks CNPq for scholarship grant (Proc. 130273/2014-7). RGF thanks FAPESP (Proc. 2013/0406-7) for a post doc fellowship grant. KDC thanks CNPq for regular financial support. We also thank Adolfo Cordero Rivera for the manuscript English revision and an anonymous reviewer for valuable comments.

RESUMO: Estudos relacionados à ocorrência de espécies e sua sazonalidade são de grande importância tanto para a elucidação da distribuição das espécies quanto para estudos focados na conservação dos habitats naturais. Nós realizamos um levantamento de espécies de Odonata e estudamos sua sazonalidade em um endêmico e ameaçado ambiente de Veredas, na Reserva Ecológica do Clube de Caça e Pesca Itororó de Uberlândia, Sudeste do Brasil. Entre os meses de Julho de 2010 e Junho de 2011, nós registramos 31 espécies de cinco diferentes famílias e 21 gêneros. A sazonalidade mostrou exercer influência na ocorrência de 24 espécies, as quais ocorreram na estação chuvosa. Por sua vez, dez espécies ocorreram nas duas estações e apenas duas espécies ocorreram somente na estação seca. Todas as espécies da subordem Anisoptera tiveram preferência por habitats lênticos. Sete das 18 espécies da subordem Zygoptera preferem ambientes lênticos, enquanto as outras 11 espécies têm preferência por ambientes lóticos. As cinco espécies das famílias Calopterygidae e Protoneuridae têm preferência por ambientes lóticos. A área de estudo exibe grande diversidade de libélulas (Anisoptera) e donzelinhas (Zygoptera), as quais são elementos importantes da cadeia trófica nas áreas alagadas do Bioma Cerrado. Este estudo visa justificar ações de conservação em áreas de Vereda que ainda são ainda pouco estudadas e ameaçadas pelo constante avanço das áreas urbanas, monocultura e pastos nas áreas de Cerrado.

PALAVRAS-CHAVE: Conservação. Lista de Espécies. Libélulas.

\section{REFERENCES}

ALTMANN, J. Observational study of behavior: sampling methods. Behaviour, v. 49, n. 3, p. 227-266, may. 1974.

ALVES-MARTINS, F.; DEL-CLARO, K.; JACOBUCCI, G. B. Sexual size dimorphism, mating system and seasonality of a Neotropical damselfly, Telebasis carmesina (Coenagrionidae). International Journal of Odonatology, v. 15, n. 4, p. 263-273, aug. 2012. http://dx.doi.org/10.1080/13887890.2012.719422

ARAÚJO, G. M.; AMARAL, A. F.; BRUNA, E. M.; VASCONCELOS, H. L. Fire drives the reproductive responses of herbaceous plants in a Neotropical swamp. Plant Ecology, v. 214, p. 1479-1484, oct. 2013. http://dx.doi.org/10.1007/s11258-013-0268-9

ARAÚJO, G. M.; BARBOSA, A. A. A.; ARANTES, A. A.; AMARAL, A. F. Composição florística de veredas no Município de Uberlândia, MG. Revista Brasileira de Botânica, v. 25, n. 4, p. 475-493, dez. 2002. http://dx.doi.org/10.1590/S0100-84042002012000012 
BISCHOF, M. M.; CAMPBELL, D. R.; LORD, J. M.; ROBERTSON, A.W. The relative importance of solitary bees and syrphid flies as pollinators of two outcrossing plant species in the New Zealand alpine. Austral Ecology, v. 38, n. 2, p. 169-176, apr. 2012. http://dx.doi.org/10.1111/j.1442-9993.2012.02389.x

BISCHOF, M. M.; HANSON, M. A.; FULTON, M. R.; KOLKA, R. K.; SEBESTYEN, S. D.; BUTLER, M. G. 2013. Invertebrate Community Patterns in Seasonal Ponds in Minnesota, USA: Response to Hydrologic and Environmental Variability. Wetlands, v. 33, p. 245-256, jan. 2013. http://dx.doi.org/10.1007/s13157-012-03749

BORROR, D. J.; TRIPLEHORN, C. A.; JOHNSON, N. F. An introduction to the study of insects. Philadelphia: Sounders College Publishing, 1989. 875 p.

COLWELL, R. K. EstimateS: Statistical estimation of species richness and shared species from samples (Software and User's guide), Version 9.1. viceroy.eeb.uconn.edu/estimates, 2000.

CORBET, P.S. Dragonflies: behaviour and ecology of Odonata. Colchester: Harley, 1999. 829 p.

CÔRTES, L. G.; ALMEIDA, M. C.; PINTO, N. S.; MARCO-JÚNIOR, P. Fogo em Veredas: Avaliação de Impactos sobre Comunidades de Odonata (Insecta). Biodiversidade Brasileira, v. 1, n. 2, p. 128-145, jul 2011.

DE ANDRADE, R. B.; BARLOW, J.; LOUZADA, J.; VAZ-DE-MELLO, F. Z.; SOUZA, M.; SILVEIRA, J. M.; COCHRANE, M. A. Quantifying responses of dung beetles to fire disturbance in tropical forests: the importance of trapping method and seasonality. PloS one, v. 6, n. 10, p. e26208, oct. 2011.

http://dx.doi.org/10.1371/journal.pone.0026208

DEL-CLARO, K.; STEFANI, V.; LANGE, D.; VILELA, A. A.; NAHAS, L.; VELASQUE, M.; TOREZANSILINGARDI, H. M. The importance of Natural History studies for a better comprehension of Animal-Plant Interaction networks. Bioscience Journal, v. 29, n. 2, p. 439-448, mar. 2013 a.

DEL-CLARO, K.; GUILLERMO-FERREIRA, R.; ALMEIDA, E. M.; ZARDINI, H.; TOREZAN-

SILINGARDI, H. M. Ants visiting the post-floral secretions of pericarpial nectaries in Palicourea rigida (Rubiaceae) provide protection against leaf herbivores but not against seed parasites. Sociobiology. v. 60, p. 217-221, jul. 2013b. http://dx.doi.org/10.13102/sociobiology.v60i3.217-221

DIJKSTRA, K. D. B.; MONAGHAN, M. T.; PAULS, S. U. Freshwater biodiversity and aquatic insect diversification. Annual Review of Entomology, v. 59, p. 143-163, jan. 2014.

http://dx.doi.org/10.1146/annurev-ento-011613-161958

FERREIRA, C. A.; TOREZAN-SILINGARDI, H. M. Effects of Floral Herbivory on Reproductive Success in Species of the Genus Banisteriopsis (Malpighiaceae) in the Brazilian Cerrado. Sociobiology, v. 60, p. 323-328, jun. 2013. http://dx.doi.org/10.1590/S0101-81752003000200008

FERREIRA-PERUQUETTI, P.; FONSECA-GESSNER, A. A. Comunidade de Odonata (Insecta) em áreas naturais de Cerrado e monocultura no nordeste do Estado de São Paulo, Brasil: relação entre o uso do solo e riqueza faunística. Revista Brasileira de Zoologia, v. 20, n. 2, p. 219-224, jun. 2003.

FONSECA, C. P. 2005. Caracterização dos Ecossistemas Aquáticos do Cerrado. In: SCARIOT, A., SOUSASILVA, J. C.; FELFILI, J. M. (Ed.). Cerrado: Ecologia, Biodiversidade e Conservação. Brasília: Ministério do Meio Ambiente, 2005. p. 25-44.

GARRISON, R. W.; VON ELLENRIEDER, N.; LOUTON, J. A. The dragonfly genera (Odonata: Anisoptera) of the New World: An illustrated and annotated key. Baltimore, Maryland: The Johns Hopkins University Press, 2006. 368 p. 
GOTTSBERGER, G.; SILBERBAUER-GOTTSBERGER, I. Life in the cerrado, a South American Tropical Seasonal Ecosystem. Vol 1. Origin, Structure, Dynamics and Plant use. Ulm, Germany: Reta Verlag, 2006. 280 p.

GRIMALDI, D.; ENGEL, M. S. Evolution of the Insects. New York: Cambridge University Press, 2005. 770 p.

GUILLERMO-FERREIRA, R.; BISPO, C. P. Description of the larva of Mnesarete pudica (Hagen in Selys, 1853) (Odonata: Calopterygidae) and notes on known genera of South American Calopterygidae larvae.

Zootaxa, n. 3482, p. 77-81, sept. 2012.

GUILLERMO-FERREIRA, R.; DEL-CLARO, K. Oviposition site selection in Oxyagrion microstigma Selys, 1876 (Odonata: Coenagrionidae) is related to aquatic vegetation structure. International Journal of Odonatology, v. 14, n. 3, p. 275-279, sept. 2011a. http://dx.doi.org/10.1080/13887890.2011.621109

GUILLERMO-FERREIRA, R.; DEL-CLARO, K. Resource defense polygyny by Hetaerina rosea Selys (Odonata: Calopterygidae): Influence of age and wing pigmentation. Neotropical Entomology, v. 40, n. 1, p. 78-84, jan. 2011b. http://dx.doi.org/10.1590/S1519-566X2011000100011

GUILLERMO-FERREIRA, R.; DEL-CLARO, K. Reproductive behavior of Acanthagrion truncatum Selys, 1876 (Odonata: Coenagrionidae). International Journal of Odonatology, v. 15, n. 4, p. 299-304, dec. $2012 \mathrm{a}$. http://dx.doi.org/10.1080/13887890.2012.740596

GUILLERMO-FERREIRA, R.; DEL-CLARO, K. Territoriality and male-biased sexual size dimorphism in Argia reclusa (Odonata: Zygoptera). Acta Ethologica, v. 15, p. 101-105, jan. 2012b.

http://dx.doi.org/10.1007/s10211-011-0114-9

GUILLERMO-FERREIRA, R.; DEL-CLARO, K. Mate recognition in Acanthagrion truncatum (Odonata: Coenagrionidae). Acta Scientiarum, v. 35, n. 3, p. 451-453, jul. 2013.

GUILLERMO-FERREIRA, R.; VILELA, D. S. Female courtship in Mnesarete lencionii? Agrion, 16:14, jan. 2012.

GUILLERMO-FERREIRA, R.; VILELA, D. S. 2013. New records of Forcipomyia (Pterobosca) incubans (Diptera: Ceratopogonidae) parasitizing wings of Odonata in Brazil. Biota Neotropica, v. 13, n. 1, jun. 2013. Disponível em: http://www.biotaneotropica.org.br/v13n1/en/abstract?shortcommunication+bn01013012013 Acesso em: 21 abr. 2015.

JUEN, L.; OLIVEIRA-JUNIOR, J. M. B. D.; SHIMANO, Y.; MENDES, T. P.; CABETTE, H. S. R. Composition and richness of Odonata (Insecta) in streams with different levels of conservation in a CerradoAmazonian Forest ecotone. Acta Amazonica, v. 44, n. 2, p. 223-233, jun. 2014. http://dx.doi.org/10.1590/S0044-59672014000200008

KALKMAN, V. J.; CLAUSNITZER, V.; DIJKSTRA, K. D. B.; ORR, A. G.; PAULSON, D. R.; VAN TOL, J. Global diversity of dragonflies (Odonata) in freshwater. Hydrobiologia, v. 595, p. 351-363, jan. 2008. http://dx.doi.org/10.1007/s10750-007-9029-x

KIM, K. C. Biodiversity, conservation and inventory: why insects matter. Biodiversity \& Conservation, v. 2, n. 3, p. 191-214, jun. 1993. http://dx.doi.org/10.1007/BF00056667

http://dx.doi.org/10.1007/BF00056668

KLINK, C. A.; MACHADO, R. B. Conservation of Brazilian Cerrado. Conservation Biology, v. 19, n. 3, p. 707-713, jun. 2005. http://dx.doi.org/10.1111/j.1523-1739.2005.00702.x 
LENCIONI, F. A. A. Damselflies of Brazil: an illustrated identification guide I - The non-Coenagrionidae families. São Paulo: All Print Editora, 2005. 323 p.

LENCIONI, F. A. A. Damselflies of Brazil: an illustrated identification guide II - Coenagrionidae. São Paulo: All Print Editora, 2006. 419 p.

MARQUES, G. D. V.; DEL-CLARO, K. The ant fauna in a Cerrado area: the influence of vegetation structure and seasonality (Hymenoptera:Formicidae). Sociobiology, v. 47, n. 1, p. 235-253, jan. 2006.

NAKAMURA, Y. Conservation of butterflies in Japan: status, actions and strategy. Journal of Insect Conservation, v. 15, p. 5-22, apr. 2011. http://dx.doi.org/10.1007/s10841-010-9299-X

OLIVEIRA-JÚNIOR, J. M. B.; CABETTE, H. S. R.; SILVA-PINTO, N.; JUEN, L. As variações na Comunidade de Odonata (Insecta) em Córregos Podem ser Preditas pelo Paradoxo do Plâncton? Explicando a Riqueza de Espécies Pela Variabilidade Ambiental. EntomoBrasilis, v. 6, n. 1, p. 1-8, jan. 2013. http://dx.doi.org/10.12741/ebrasilis.v6i1.250

OLIVEIRA, P. S.; MARQUIS, R. J. Introduction: Development of Research in the Cerrados. In: The Cerrados of Brazil: Ecology and natural history of a neotropical savanna. New York: Columbia University Press, 2002. p 1-12.

OPLER, P. A. North American Problems and Perspectives in Insect Conservation. In: COLLINS, N. M. (Ed.). The conservation of insects and their habitats. London: Academic Press, p. 9-32, 1991. http://dx.doi.org/10.1016/b978-0-12-181370-3.50008-7

SAMWAYS, M. J.; HAMER, M.; VELDTMAN, J. Development and Future of Insect Conservation in South Africa. In: Insect Conservation: Past, Present and Prospect, pp. 245-278, Dordrecht: Springer, 2012. http://dx.doi.org/10.1007/978-94-007-2963-6_11

VILELA, A. A.; TOREZAN-SILINGARDI, H. M.; DEL-CLARO, K. Conditional outcomes in ant-plantherbivore interactions influenced by sequential flowering. Flora, v. 209, p. 359-366, jul. 2014.

http://dx.doi.org/10.1016/j.flora.2014.04.004

von ELLENRIEDER, N. 2009. In: IUCN. 2013. IUCN Red List of Threatened Species. Version 2013.1. Disponível em: http://www.iucnredlist.org/. Acesso em: 30 ago. 2013.

WARD, L; MILL, P. J. Habitat factors influencing the presence of adult Calopteryx splendens (Odonata: Zygoptera). European Journal of Entomology, v. 102, n. 1, p. 47-51, ago. 2005. 